\title{
A Case of IgG4-Related Disease With Sino-Nasal Involvement
}

\author{
Young Seok Han $^{1}{ }^{(\mathbb{D}}$, Jun Sang Cha ${ }^{1}$, Min Jung Jung ${ }^{2}$, and Joo Yeon Kim ${ }^{1}(\mathbb{D}$ \\ Departments of ${ }^{1}$ Otolaryngology-Head and Neck Surgery and ${ }^{2}$ Pathology, Kosin University College of Medicine, Busan, Korea \\ 비부비동을 침범한 IgG4-연관 질환 1예 \\ 한영석 ${ }^{1} \cdot$ 차준상 ${ }^{1}$ - 정민정 ${ }^{2} \cdot$ 김주연 ${ }^{1}$ \\ 고신대학교 의과대학 ${ }^{1}$ 이비인후과학교실, ${ }^{2}$ 병리과학교실
}

\author{
Received July 4, 2021 \\ Revised September 14, 2021 \\ Accepted October 15, 2021 \\ Address for correspondence \\ Joo Yeon Kim, MD, PhD \\ Department of Otolaryngology- \\ Head and Neck Surgery, \\ Kosin University \\ College of Medicine, \\ 262 Gamcheon-ro, Seo-gu, \\ Busan 49267, Korea \\ Tel $+82-51-990-6258$ \\ Fax $+82-51-245-8539$ \\ E-mailoooo95@hanmail.net
}

IgG4-related diseases are immune-mediated diseases associated with fibroinflammatory lesions and are known to invade almost all organs of the human body. In the head and neck area, it rarely occurs in the nasal cavity and sinuses. Diagnosis is made by combining clinical features, serological, imaging, and histopathological findings, and glucocorticoids are known as the main treatment. In general, surgical resection is not regarded as a curative treatment option. Here we report a case with literature review of IgG4-related diseases with sino-nasal involvement experiencing prominent nasal symptom relief and remission with surgical treatment, which did not respond well to oral steroid in a 70-year-old male patient.

Korean J Otorhinolaryngol-Head Neck Surg 2022;65(11):705-12

Keywords IgG4-related disease; Sinuses, paranasal; Surgery.

\section{서 론}

$\mathrm{IgG4}$-연관 질환은 섬유염증성 병변(fibroinflammatory lesion)과 연관된 면역 매개 질환으로 인체의 모든 장기에 침 범될 수 있는 것으로 알려져 있다. ${ }^{1)}$ 대개 다발성 장기를 침범 하는 만성 염증성 전신 질환의 형태로 나타나지만 두경부 영 역에서는 악하선, 이하선, 설하선 등 주요 침샘이나 눈물샘, 갑상선 및 뇌하수체에 주로 발생하고 비강과 부비동에 발생 하는 경우는 극히 드물다. 임상 양상, 혈청학적, 영상학적 그 리고 병리조직학적 검사 소견을 종합하여 진단하며, 글루코 코르티코이드가 주된 치료로 알려져 있다. ${ }^{2,3)}$

저자들은 70세 남자 환자에서 발생한 경구 스테로이드 치 료에 잘 반응하지 않는 비부비동을 침범한 $\mathrm{IgG4}$-연관 질환

This is an Open Access article distributed under the terms of the Creative Commons Attribution Non-Commercial License (https://creativecommons.org/licenses/by-nc/4.0) which permits unrestricted non-commercial use, distribution, and reproduction in any medium, provided the original work is properly cited.
1 예를 내과적 치료와 함께 치료적 목적의 수술로써 증상 완 화와 관해를 치험하였기에 문헌 고찰과 함께 이를 보고하고 자 한다.

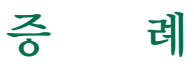

70세 남자가 약 2달간 $10 \mathrm{~kg}$ 의 체중감소, 간헐적인 발열과 오한으로 타원에 내원하였다. 환자는 고혈압으로 복약 중이었 으며, 2 년 전 만성비부비동염 증상으로 타원에서 양측 부비동 내시경수술을 시행 받은 과거력이 있었다. 흥부 컴퓨터단층 촬영상 주로 양측 폐하엽에 보이는 다발성 폐경결(multifocal consolidations) 소견으로 폐렴에 준하여 항생제를 사용하였 음에도 발열이 지속되었다. 혈액 검사상 알부민(albumin) 감 소, 알부민글로불린비(albumin/globulin ratio)가 1 미만으로 확인되어 추가 검사 및 조치를 위해 본원 호흡기내과에 입원 하였다. 
흥부 컴퓨터단층촬영상 주로 양측 폐하엽에 기관지벽비후 (bronchial wall thickening)를 동반한 다발성 폐경결이 관찰 되었고, 이는 결절(nodule) 또는 종물(mass) 형태를 보이고 있어 악성(malignancy), 육아종성 질환(granulomatous disease), 혈관염(vasculitis) 등을 배제할 수 없었다. 혈청 검사상 $\operatorname{IgG} 2227.5 \mathrm{mg} / \mathrm{dL}$ (참고치 700-1600 mg/dL), IgG4 4960.0 $\mathrm{mg} / \mathrm{L}$ (참고치 30-2010 mg/L)로 나타났고, 양전자방출단층 촬영-컴퓨터단층촬영(PET-CT)에서 양측 폐하엽과 우측 비 부비동에 IgG4-연관 질환(IgG4-related disease)과 대사 증 가 정도가 유사한 다발성 병변이 확인되었다(Fig. 1). 폐병변 에 대한 병리조직검사상 림프구 침윤(lymphocytic infiltration)이 관찰되었고, $\operatorname{IgG}$ 부분 양성(focally positive), $\operatorname{IgG} 4$ 극 히 일부 양성(positive in very few lymphocytes) 소견이 보였 다. 그 외 복부 컴퓨터단층촬영, 식도위십이지장내시경, 대장 내시경 및 골수검사상에는 특이 소견을 보이지 않았다.

환자는 비강 증상으로 후비루, 양측 코막힘, 비강 건조감 (dry nose), 가피(crust) 형성과 후각 저하를 호소하였고, 내 시경 소견상 우측 중비도에 가피와 부종, 좌측 비중격과 중비 갑개 사이 유착 소견이 관찰되었다(Fig. $2 \mathrm{~A}$ and B). 컴퓨터 단층촬영에서는 우측 상악동, 우측 사골동과 우측 접형동에 국한된 부비동염 소견이 확인되었다(Fig. $3 \mathrm{~A}$ and B). 우측 비강 측벽과 우측 중비도의 점막 비후 소견에 대하여 $\mathrm{IgG} 4-$
연관 질환과의 관련성이나 기타 육아종성 질환을 의심하여 국소마취하에 펀치생검(punch biopsy)을 실시하였다. 비강 병 리조직학적 검사상 hematoxylin and eosin $(\mathrm{H} \& \mathrm{E})$ 검사에서 림프형질세포(lymphoplasma cell)의 밀집된 침윤(dense infiltration)과 소용돌이 섬유화(storiform fibrosis) 소견이 확 인되었다. 면역조직화학검사에서 $\operatorname{IgG} 4$ 양성을 보이는 형질 세 포(IgG4+ plasma cell)가 고배율 시야에서 100개 이상 관찰 되었고(>100/HPF), $\mathrm{IgG} 4 / \mathrm{IgG}$ 양성 형질세포 비율이 약 $30 \%$ 로 측정되었다(Fig. 4A-E).

결론적으로 양측 폐와 더불어 우측 비강과 우측 부비동을 침범한 $\mathrm{IgG} 4$-연관질환으로 진단하였으며 이에 경구 스테로 이드(prednisolone $40 \mathrm{mg} / \mathrm{day}$ ) 투여를 시작하였다. 폐병변에 대하여 투여 기간 동안 단순흥부방사선사진으로 추적 관찰하 였고, 첫 2개월간 투여 후 호전 양상 보여 중단하였다(prednisolone $40 \mathrm{mg} / \mathrm{day} 4$ 주, $30 \mathrm{mg} /$ day 1주, $20 \mathrm{mg} /$ day 1주, $10 \mathrm{mg} / \mathrm{day} 1$ 주, $5 \mathrm{mg} / \mathrm{day}$ 1주). 이후 2개월 뒤 확인한 추적 흥부 컴퓨터단층촬영상 양측 폐하부의 잔존 병변은 유의한 변화 보이지 않았고, 좌측 폐상엽에 새롭게 진행된 소견이 확 인되었다. 이에 스테로이드 투여를 저용량으로 재시작하였고 (prednisolone $10 \mathrm{mg} / \mathrm{day} 8$ 주, 5mg/day 8주), 추적 흥부 컴 퓨터단층촬영상 양측 폐하부와 좌측 폐상엽 병변 모두 호전 된 소견이 확인되었다.
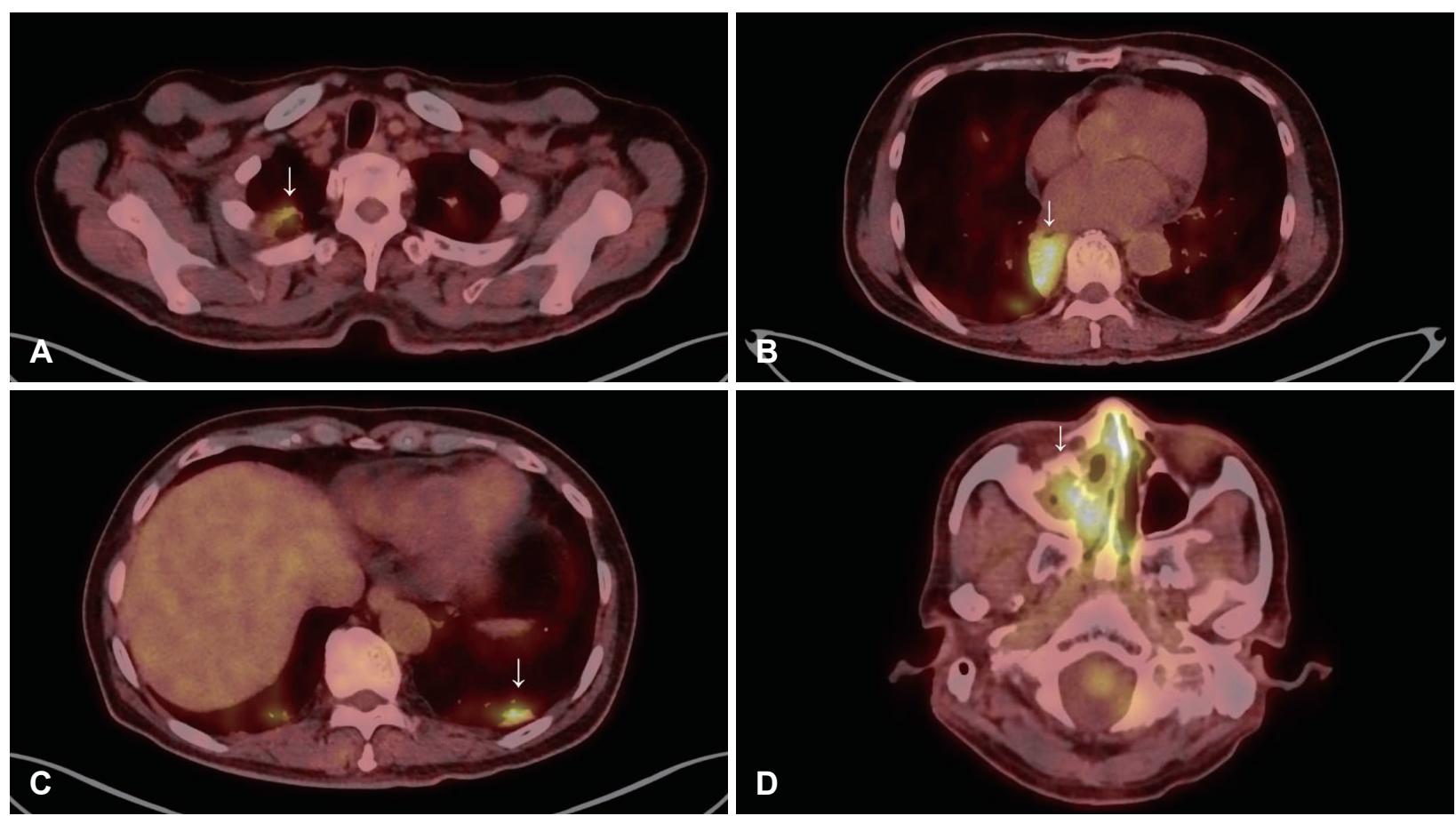

Fig. 1. Initial PET-CT findings. A-C: PET-CT showed hypermetabolic mass-like consolidations and nodules in right upper lobe and both lower lobe suggesting possible Inflammation. D: Hypermetaoblic infiltrations in right maxillary sinus and nasal cavity suggesting sinusitis. For both lung and sinonasal lesions, fibroinflammatory diseases including IgG4-related disorder is suspected and tissue confirmations have done. Arrows $(\downarrow)$ indicate lgG4-related lung and sinonasal lesions. 

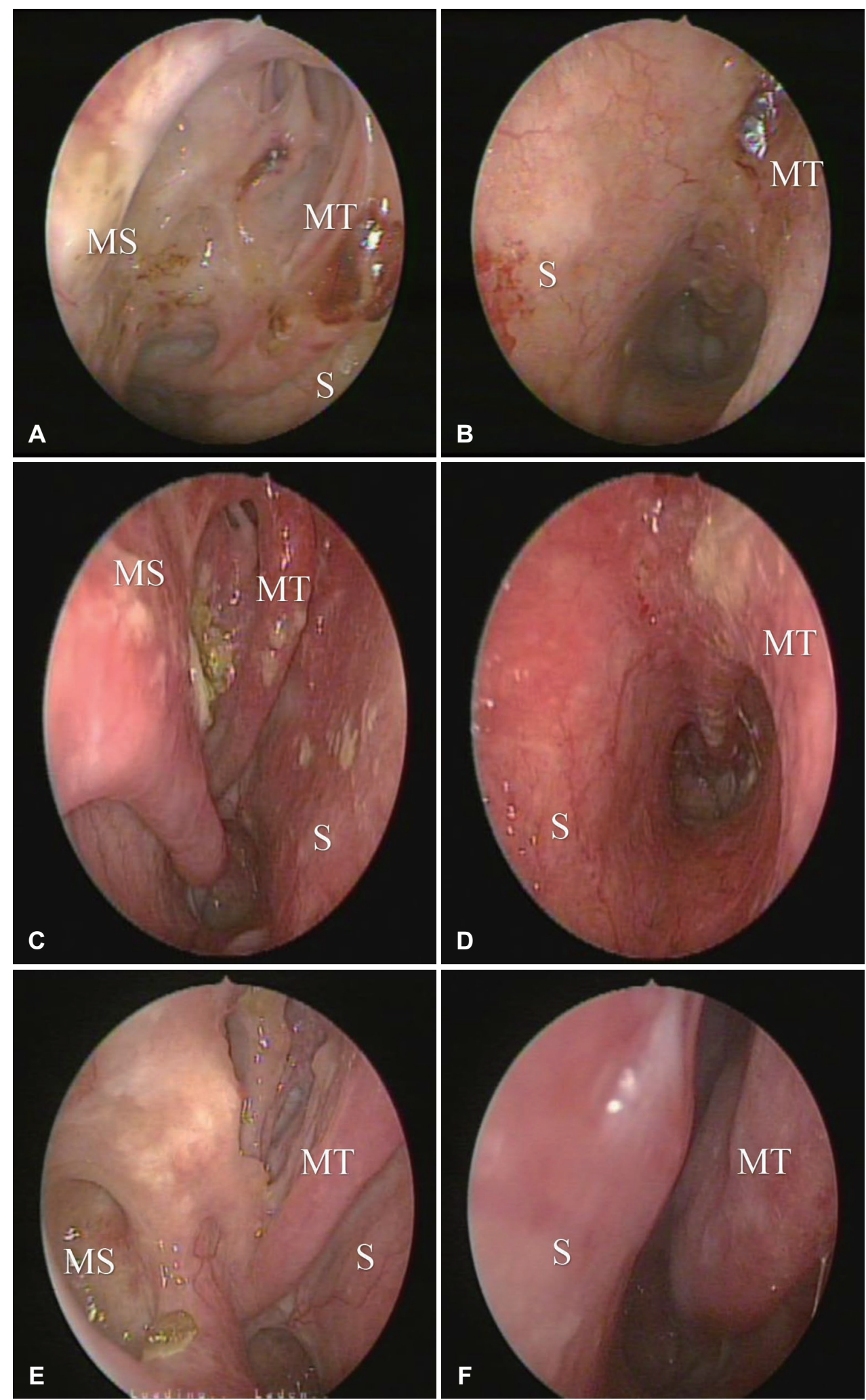

Fig. 2. Initial-, pre-, and post-operative endoscopic findings. A: In initial endoscopic finding, mucosal swelling and fibrotic change with multiple crusts were shown at right peri-maxillary natural ostium and middle tubinate. B: Synechia between left MT and S. C: In pre-operative endoscopic finding, even after 6 months of systemic steroid treatment, right nasal cavity lateral wall lesions were remained. D: Synechia between left MT and S was also maintained. E: In post-operative endoscopic finding, right maxillary natural ostium has widened, and the adjacent tissues demonstrated well healed mucosa with prominent decrease of crust formation. F: After synechiolysis, left middle meatus has been restored with healed mucosa. MT, middle turbinate; S, nasal septum; MS, maxillary sinus. 

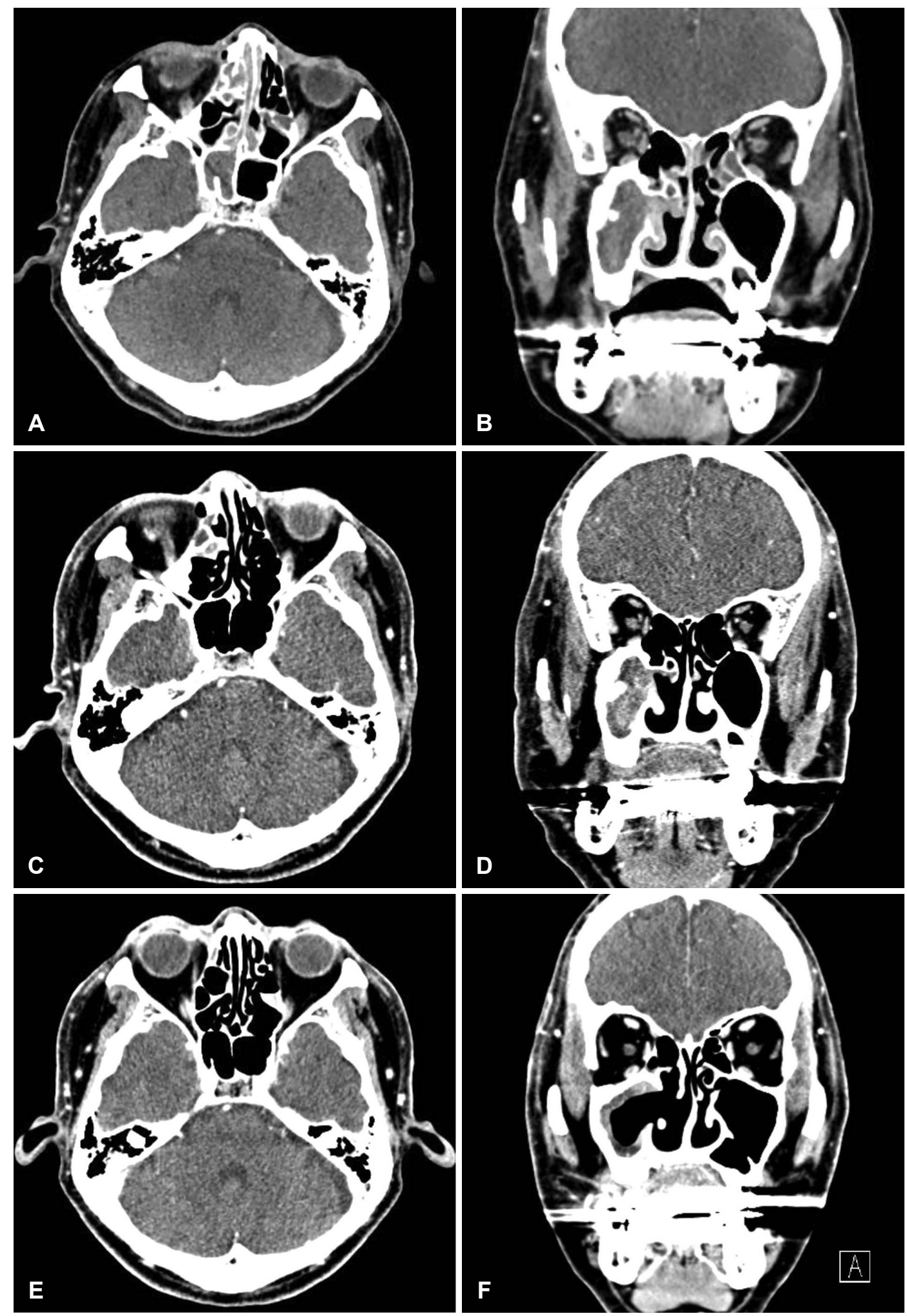

Fig. 3. Initial, pre-, and post-operative CT findings. A and B: In initial CT images, homogenous soft tissue densities were shown in right ethmoid sinus and sphenoid sinus (A), right MS (B) without bone destruction. C and D: In pre-operative CT images, even after 6 months of systemic steroid treatment, homogenous soft tissue densities were remained in right ethmoid sinus (C) and right MS (D). E and F: In post-operative 1 month CT images, homogenous soft tissue densities were disappeared in right ethmoid sinus (E) and right MS (F). MS, maxillary sinus. 

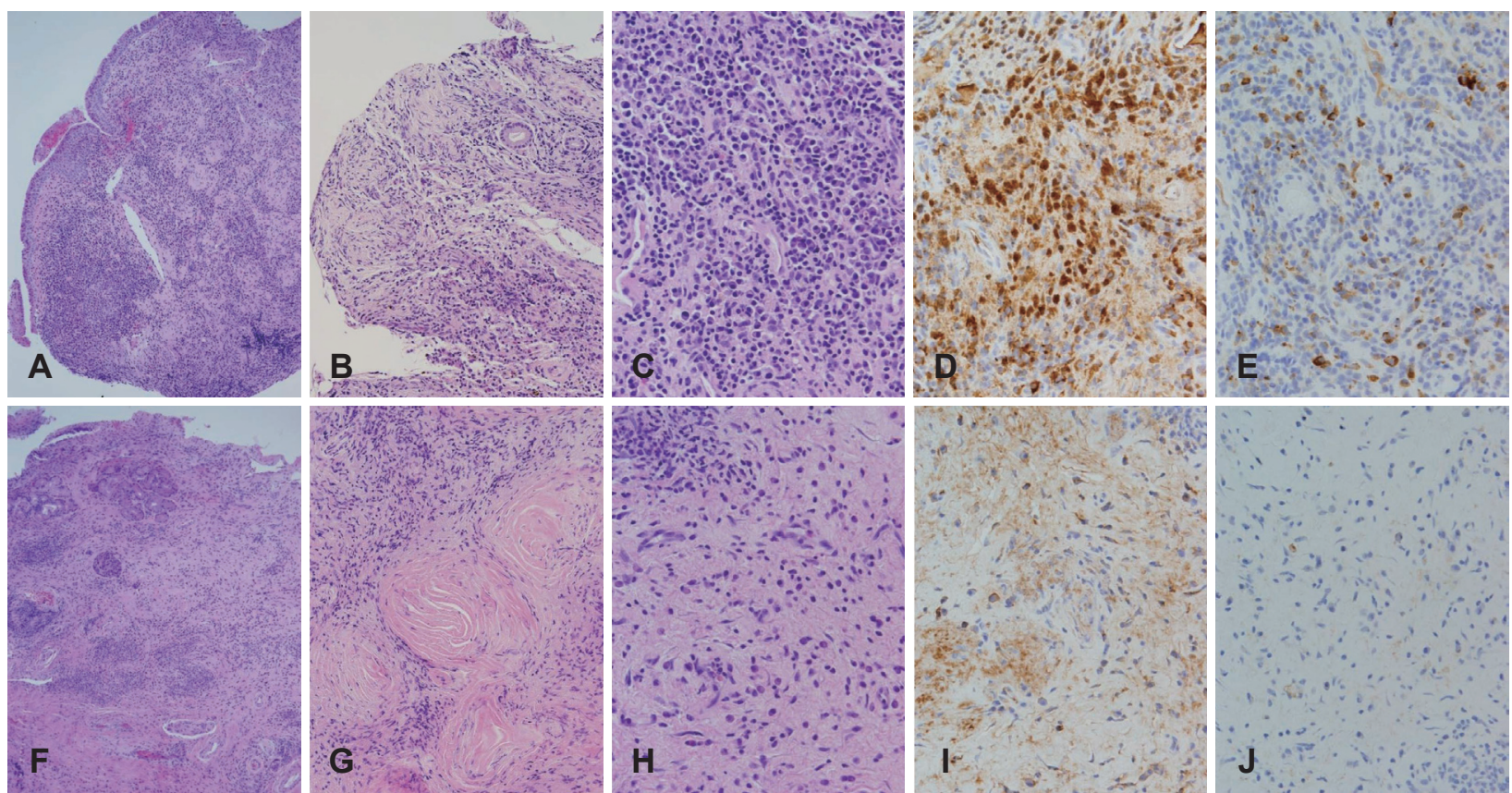

Fig. 4. Pre-operative (A-E) and post-operative (F-J) pathologic findings of nasal mucosa. A-C: An initial biopsy of the nasal mucosa exhibits dense infiltration of lymphoplasma cells and fibrosis. D-E: The immunohistochemical staining exhibits high levels of lgG4-positive plasma cell count and ratio of IgG4-positive/lgG-positive plasma cells. F-H: After steroid therapy, the mucosal inflammation is reduced, however storiform fibrosis is still prominent. I and J: The number of IgG-positive (I) and IgG4-positive plasma cells (J) decreased. Hematoxylin and eosin staining, $\times 100$ magnification (A), $\times 200$ magnification (B), $\times 400$ magnification (C), immunohistochemical staining for $\operatorname{lgG}, \times 400$ magnification (D), immunohistochemical staining for IgG4, $\times 400$ magnification (E), hematoxylin and eosin staining, $\times 100$ magnification $(F), \times 200$ magnification $(G)$ and $\times 400$ magnification $(H)$, immunohistochemical staining for lgG, $\times 400$ magnification $(\mathrm{I})$ and immunohistochemical staining for lgG4, $\times 400$ magnification $(\mathrm{J})$.

우측 비강과 우측 부비동 병변에 대하여서는 6개월간의 경구 스테로이드와 더불어 만성비부비동염에 준하여 국소 스테로이드 스프레이, 생리식염수 비강세척, 항생제를 포함한 보조적 치료를 시행하였다. 그럼에도 불구하고 우측 접형동 병변만 소실되었을 뿐 후비루, 양측 코막힘 등 유의한 증상 호전은 없었으며, 우측 비강 측벽, 우측 사골동과 우측 상악 동 병변은 비강 내시경 소견(Fig. $2 \mathrm{C}$ and D)과 컴퓨터단층촬 영상 호전이 없었다(Fig. $3 \mathrm{C}$ and D). 지속되는 병변과 증상을 해결하기 위해 근치적 목적의 부비동 내시경수술을 계획하였 고, 우측 중비도 상악동개방술(middle meatus antrostomy), 우측 전사골동절제술(anterior ethmoidectomy), 좌측 중비갑 개와 비중격 유착박리술(synechiolysis)을 시행하였다. 수술 중 우측 중비도 점막에 대한 펀치생검을 진행하였으며, $\mathrm{H \& E}$ 염색에서 림프형질세포 침윤 소견과 소용돌이 섬유화가 확인 되었다. 림프형질세포 침윤 정도와 $\mathrm{IgG}$ 와 $\mathrm{IgG}$ 양성 형질 세 포(plasma cell) 수는 스테로이드 사용 전 시행한 조직검사보 다 감소한 것으로 나타났다(Fig. $4 \mathrm{~F}-\mathrm{J}$ ). 술후 비강 건조감과 가피 형성이 현저히 감소하였고, 후각도 회복되었으며 점막 소견도 정상화되었다(Fig. $2 \mathrm{E}$ and F). 수술 후 1개월째 확인 한 추적 컴퓨터단층촬영상 우측 사골동, 우측 상악동 병변 도 모두 소실되었다(Fig. $3 \mathrm{E}$ and F). 이후 재발 없이 잔존한
폐병변에 대하여 저용량 스테로이드(prednisolone $5 \mathrm{mg} / \mathrm{day}$ ) 투약하며 6개월째 추적 관찰 중이다.

\section{고 찰}

$\mathrm{IgG4}$-연관 질환은 섬유염증성 병변과 연관된 면역 매개 질환이다.1 이 질환에 대한 역학은 아직까지도 충분히 알려져 있지 않으나, 2003년 이후 별개의 질환으로 인식된 뒤부터는 세계적으로 다양하게 보고되고 있어 사실상 인체의 모든 장 기에 침범될 수 있다는 것이 알려져 있다. ${ }^{2)}$ 대개 다발성 장기 를 침범하는 만성 염증성 전신 질환의 형태로 나타나고 종종 악성, 만성 감염이나 쇼그렌 증후군 또는 혈관염 등과 같은 기타 면역 매개 질환과 오인되기도 한다. 발병기전에 대하여 서는 2007년 IgG4-연관 경화성 췌장염의 연구에서 조력T2 세포(Th2 cell)와 사이토카인의 과분비와 관련되어 있다고 보고되었고, 최근에는 $\mathrm{CD} 4$ 세포독성 $\mathrm{T}$ 세포 $\mathrm{CD} 4$ cytotoxic $\mathrm{T}$ cells)에 형질모세포(plasmablast) 혹은 B세포가 제시하는 자가항원(autoantigen)과 여포 보조T세포(follicular T helper cell)의 상호작용에 의해 유발된 면역 질환으로 이해되고 있 다. ${ }^{3)} \mathrm{IgG} 4$-연관 질환이 모든 장기에 침범 가능하나 특히 침 샘, 눈물샘 및 췌장 등 외분비 기관 위주로 침범되는 사실로 
미루어 보아 외분비 기관과 관련된 공통적인 자가면역 표적 항원이 원인으로 제시되고 있으며, 질환을 야기하는 자가항원 으로 현재까지 galectin-3, annexin-A11, laminin-511, prohibitin 등이 제기되고 있다.")

두경부 영역에서는 주로 악하선, 이하선, 설하선 등 주요 침 샘이나 눈물샘, 갑상선 및 뇌하수체에 IgG4 양성 형질 세포 침윤이 보고되었다. 그러나 비강 및 부비동을 침범하는 경우 는 세계적으로도 드물고, 국내에서는 현재까지 총 6예가 보고 되었다(Table 1). ${ }^{5-8)}$ 비부비동 침범을 보이는 $\mathrm{IgG4}$-연관 질환 은 비교적 나이가 많은 남자에서 비교적 높은 빈도로 보고되 었으나, ${ }^{9)}$ 국내에서는 본 증례를 포함한 7예 중 2예를 제외하 면 모두 여자였다. 증상으로는 흔히 코막힘, 후비루, 비루 등 만성비부비동염의 임상양상을 보이며 반복적 비출혈, 가피 형 성, 안면부 통증 등의 국소 침습적 질환의 특징을 보이기도 한다. ${ }^{5-9)}$ 본 증례에서는 후비루(SNOT-22 3점)가 주증상으로 나타났으며, 양측 코막힘(SNOT-22 1점), 경미한 후각 저하 (SNOT-22 1점) 및 비 건조감(Visual Analogue Scale [VAS] 2점)과 잦은 가피 형성(VAS 2점)의 임상증상을 보였다.

$\mathrm{IgG4}$-연관 비부비동 질환은 대개 다른 장기의 침범을 동 반하는 것으로 알려졌으나 비부비동만 단독으로 침범하는 경 우도 있다. ${ }^{10)}$ 국내에서는 뇌하수체 침범을 동반한 사례가 1 예 있고, 그 외 5예는 모두 비부비동 단독 침범 사례이다. ${ }^{5-9)}$ 본 증례는 양측 폐 침범이 동반되었다. 비부비동 내 침범 위치와 관련하여서는 고립된 접형동 병변이나 우측 상악동 및 비중 격과 이하선에 동시에 발생한 경우도 있지만 대부분의 경우 부비강 내에서 발생하며, 상악동, 사골동, 비중격 순으로 침범 이 흔하다. 국내 보고 사례에서도 유사하게 상악동, 사골동, 비중격, 전두동, 접형동 순으로 침범이 흔한 것으로 나타났으 며, 본 증례에서도 우측 상악동, 우측 사골동, 우측 접형동을 침범하는 양상이었다. ${ }^{5-8)}$

$\mathrm{IgG} 4$-연관 질환 진단은 최근 제시된 진단 기준에 따르면 임상 양상, 혈청학적, 영상학적 그리고 병리조직학적 검사 소 견을 모두 종합하여 진단한다. ${ }^{11)} \mathrm{IgG} 4$-연관 질환의 개념이 막 정립되기 시작한 초기에는 대부분의 진단이 병리조직학적 검사에 의존하였고, 국내 보고 사례들처럼 악성이나 육아종 성 질환 의심하 시행한 진단적 목적의 수술에서 우연히 확인 된 경우가 대부분이다. ${ }^{5,68} \mathrm{IgG} 4$-연관 질환의 특징적 병리조 직검사 소견으로는 림프형질세포 침윤, 소용돌이 섬유화, 폐 색정맥염(obliterative phlebitis)의 세 가지 조직학 특징 중 두 가지 이상을 보일 경우 진단할 수 있으며, 그 중에서도 림 프형질세포 침윤과 소용돌이 섬유화가 특징적이다. 폐색정맥 염이나 호산구 침윤(eosinophilic infiltration) 소견은 IgG4연관 질환의 대략 절반 정도의 환자에서만 관찰된다. ${ }^{3)}$ 혈청
$\mathrm{IgG} 4$ 농도의 상승이나 $\mathrm{IgG} 4$-연관 질환의 전형적인 양상으 로서의 다른 장기 침범의 증거 등이 있으면 진단에 도움이 된 다. ${ }^{11)}$ 조직에서 $\mathrm{IgG} 4 / \mathrm{IgG}$ 비의 증가 $(>40 \%)$ 혹은 고배율 시야 (HPF, ×400)에서 IgG4 양성 형질 세포 숫자의 증가 역시 진 단적 가치가 있으며, ${ }^{11)}$ 비부비동을 침범한 경우 해외 증례들 에서는 30-150/HPF 이상, ${ }^{9)}$ 국내 증례들에서는 30-100/HPF 이상으로 보고되었다. ${ }^{5-8)}$ 본 증례에서는 다수의 림프 형질 세 포 침윤과 소용돌이 섬유화가 관찰되었고, $\mathrm{IgG} 4$ 양성 형질 세포 수가 $100 / \mathrm{HPF}$ 로 확인되어 $\mathrm{IgG} 4$-연관 비부비동 질환 으로 진단하였다.

영상학적으로는 컴퓨터단층촬영이나 자기공명영상에서 비 특이적으로 나타나기 때문에 베게너육아종, 림프종, 진균 감 염과 감별이 필요하다. 컴퓨터단층촬영에서는 골 파괴를 동 반하거나 동반하지 않는 균질한 연부조직 음영을 보이며, 자 기공명영상의 경우 $\mathrm{T} 2$ 에서 주변 정상 비부비동 점막에 비하 여 저 신호강도 및 균일한 조영 증강을 보인다. ${ }^{10)}$ 본 증례의 컴 퓨터단층촬영 상에서는 우측 상악동, 사골동과 접형동에 골 파괴를 동반하지 않는 균질한 연부조직 음영이 관찰되었다.

$\mathrm{IgG4}$-연관 질환의 치료 목표는 염증 반응을 줄이거나 관 해된 상태(remission)를 유지시키고, 치료의 부작용을 최소화 하며 침범된 장기 기능을 보존하는 것이다. ${ }^{3)}$ 증상이 없더라도 주요 장기에서 질병의 진행이 확인된 경우나, 활동성이거나 증상이 있는 $\mathrm{IgG} 4$-연관 질환 환자들은 모두 치료가 필요하 며 그 중 일부는 치료가 절박(urgent)하다.,12) 치료 후 호전되 더라도 수 개월에서 수년 이후에 초침범 장기(initial involved organ) 이 외의 주요 장기들(major organs)에서 재발하는 경 우가 있기 때문에 6개월마다 정기적으로 새로운 증상 발현 여부와 전체혈구계산(complete blood count), IgG 아계(subclasses), IgE나 C3, C4 보체 혈청검사 등을 포함하여 경과관 찰하는 것이 적절하다. ${ }^{3,12}$

대부분의 $\mathrm{IgG} 4$-연관 질환에 대하여 글루코코르티코이드 (glucocorticoid)가 치료의 기본이 된다. $\mathrm{IgG} 4$-연관 질환에 대한 2019 American College of Rheumatology/European League Against Rheumatism 분류 기준에 따르면, 적절한 용량의 글루코코르티코이드 치료에도 불구하고 객관적인 치 료 반응이 나타나지 않을 경우 $\mathrm{IgG} 4$-연관 질환을 배제할 수 있다. ${ }^{11)}$ 비부비동을 침범한 경우 prednisolone 30-40 mg/day 용량을 6 개월에서 18 개월까지 사용하여 치료한 사례들이 보 고된 바 있으며, ${ }^{13)}$ 국내에 보고된 6예 전부 글루코코르티코이 드를 사용하였고 경과 관찰 기간은 2 개월에서 4년으로 상이 하나 모두 효과적이었다고 보고하였다. ${ }^{5-8)}$ 본 증례에서는 6 개 월간의 경구 스테로이드 투여 후 폐 병변에서는 호전을 보였 으나 비부비동 관련 증상이나 영상학적 소견에서는 전혀 호전 
IgG4-Related Disease With Sino-Nasal Involvement I Han YS, et al.

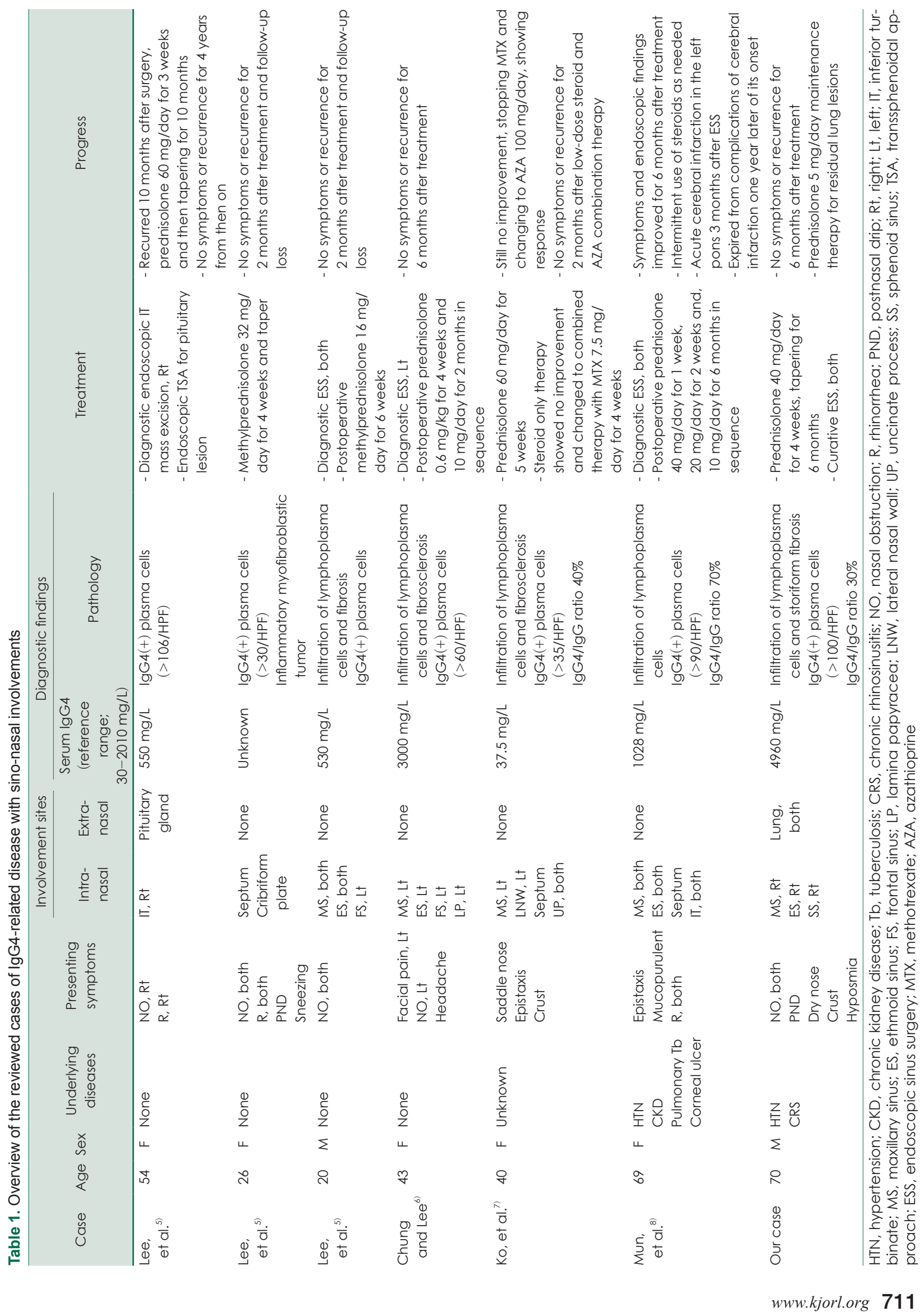


이 없었다. 그럼에도 스테로이드 치료 후 병리조직학적으로는 림프형질세포 침윤 정도와 면역조직화학검사에서 $\mathrm{IgG}$ 와 $\mathrm{IgG} 4$ 양성 형질 세포수가 감소한 것으로 미루어보아 여전히 스테로 이드 치료는 병행하는 것이 치료에 도움될 것으로 사료된다. 대부분의 상황에서 글루코코르티코이드 단독 치료가 이용 되지만, 종종 스테로이드와 항류마티스 약물(disease modifying anti-rheumatic drugs)의 병합 요법도 사용된다. 주로 사용되는 항류마티스 약물로는 azathioprine, mycophenolate mofetil, methotrexate, leflunomide와 cyclophosphamide가 있다. ${ }^{12)}$ 항류마티스 약물은 글루코코르티코이드 독 성을 줄이는 목적으로 사용하나, 아직까지 그 효능(efficacy) 에 대한 임상적인 근거는 충분하지 않다. ${ }^{3)} 104$ 명을 대상으로 한 글루코코르티코이드 단독 요법과 글루코코르티코이 드-cyclophosphamide (50-100 mg/day) 병합 요법에 대한 전향적 코호트 비교 연구에서 두 요법 모두 관해를 유도하는 데는 동일하게 효과적이었으나, 병합 요법에서 12 개월의 경과 관찰 기간 동안 재발율이 낮게 나타났다고 보고한 바 있다. ${ }^{14)}$ 국내에서는 5주간의 prednisolone $60 \mathrm{mg} / \mathrm{day}$ 단독 요법 후 호전 없어 저용량 스테로이드와 methotrexate $7.5 \mathrm{mg} / \mathrm{day}$ 및 azathioprine $100 \mathrm{mg} / \mathrm{day}$ 과 병합 요법으로 치료한 사례 가 있다. ${ }^{7)}$

대부분의 나라에서 비용 문제로 활용도가 떨어지지만 글루 코코르티코이드 치료에도 효과가 미미하거나 재발하는 경우 생물학적 제제(biologic agents) 사용도 고려할 수 있다. B세 포 고갈(B-cell depletion)을 유도하는 anti CD20-antibody 인 rituximab를 통해 관해를 기대하거나 스테로이드 용량을 줄일 수 있으며, ${ }^{15)}$ 최근에는 $\mathrm{IgG4}$-연관 질환에 대한 병태생 리학적 이해가 높아지면서 CD4 세포독성 T세포 중 특히 SLAMF7을 발현하는 T세포에 대한 생물학적 제제인 elotuzumab에 대한 연구도 활발히 진행중이다. ${ }^{3)}$

스테로이드 치료에도 뚜렷한 호전이 없는 경우, 앞서 언급 하였듯이 항류마티스 약물과의 병합 요법이나 생물학적 제제 등을 사용한 내과적 접근이 일반적이나 효능에 대해서는 아 직 논란이 있다. ${ }^{3)}$ 한편, 대체 약물 대신 수술을 진행한 보고 들이 있으나 대부분 진단적 목적으로 시행되었고, 수술 후 일 부 증상 호전을 보였다. ${ }^{13)}$ 본 증례의 경우 $\mathrm{IgG} 4$-연관 비부비 동 질환으로 심한 부비강 내 국소 증상을 호소하였고 스테로 이드 치료에 반응이 없어 치료적 목적으로 수술을 계획하였 으며, 수술 후 부비강 병변의 관해와 부비강 증상 완전 해소 및 6개월 간 특이소견 없이 경과 관찰 중이다. 따라서, $\mathrm{IgG} 4-$ 연관 질환의 병태생리가 전신을 침범하는 자가면역 질환임은 사실이지만, 잔존 병변 제거와 증상 완화 및 삶의 질 개선을 위해서는 적극적인 수술적 치료가 도움을 줄 수 있겠다.

\section{Acknowledgments \\ None}

\section{Author Contribution}

Conceptualization: Joo Yeon Kim. Data curation: Young Seok Han, Jun Sang Cha. Formal analysis: Min Jung Jung, Joo Yeon Kim. Investigation: Young Seok Han. Methodology: Joo Yeon Kim. Resources: Min Jung Jung. Supervision: Joo Yeon Kim. Visualization: Young Seok Han. Writing — original draft: Young Seok Han. Writing—review \& editing: Joo Yeon Kim.

\section{ORCIDs}

Joo Yeon Kim https://orcid.org/0000-0001-8432-6056

Young Seok Han https://orcid.org/0000-0002-4138-6857

\section{REFERENCES}

1) Stone JH, Zen Y, Deshpande V. IgG4-related disease. N Engl J Med 2012;366(6):539-51.

2) Kamisawa T, Funata N, Hayashi Y, Eishi Y, Koike M, Tsuruta K, et al. A new clinicopathological entity of IgG4-related autoimmune disease. J Gastroenterol 2003;38(10):982-4.

3) Zhang W, Stone JH. Management of IgG4-related disease. Lancet Rheumatol 2019;1(1):e55-65.

4) Umehara H, Okazaki K, Masaki Y, Kawano M, Yamamoto M, Saeki T, et al. Comprehensive diagnostic criteria for IgG4-related disease (IgG4-RD), 2011. Mod Rheumatol 2012;22(1):21-30.

5) Lee JR, Lee BJ, Chung YS. Three cases of IgG4-related sclerosing disease in nasal cavity. J Rhinol 2016;23(1):44-8.

6) Chung J, Lee JH. A case of immunoglobulin G4-related sclerosing disease of the paranasal sinus mimicking nasal malignancy. $\mathrm{J}$ Rhinol 2017;24(1):60-4.

7) Ko SH, Yoon HJ, Zheng T, Jeong JH. A case of immunoglobulin G4-related sclerosing disease not responded to steroid in nasal cavity. J Rhinol 2017;24(2):138-42.

8) Mun SJ, Shin NR, Koh JH, Roh HJ. A case of IgG4 related disease in the nasal cavity and paranasal sinus: A rare cause of nasal bleeding. J Clin Otolaryngol Head Neck Surg 2019;30(1):116-21.

9) Vandjelovic ND, Humphreys IM. Immunoglobulin G4-related sclerosing disease of the paranasal sinuses: A case report and literature review. Allergy Rhinol (Providence) 2016;7(2):85-9.

10) Fujita A, Sakai O, Chapman MN, Sugimoto H. IgG4-related disease of the head and neck: CT and MR imaging manifestations. Radiographics 2012;32(7):1945-58.

11) Wallace ZS, Naden RP, Chari S, Choi H, Della-Torre E, Dicaire JF, et al. The 2019 American College of Rheumatology/European League Against Rheumatism classification criteria for IgG4related disease. Arthritis Rheumatol 2020;72(1):7-19.

12) Khosroshahi A, Wallace ZS, Crowe JL, Akamizu T, Azumi A, Carruthers $\mathrm{MN}$, et al. International consensus guidance statement on the management and treatment of $\mathrm{IgG} 4$-related disease. Arthritis Rheumatol 2015;67(7):1688-99.

13) Song BH, Baiyee D, Liang J. A rare and emerging entity: Sinonasal IgG4-related sclerosing disease. Allergy Rhinol (Providence) 2015; 6(3):151-7.

14) Yunyun F, Yu C, Panpan Z, Hua C, Di W, Lidan Z, et al. Efficacy of cyclophosphamide treatment for immunoglobulin G4-related disease with addition of glucocorticoids. Sci Rep 2017;7(1):6195.

15) Khosroshahi A, Carruthers MN, Deshpande V, Unizony S, Bloch $\mathrm{DB}$, Stone JH. Rituximab for the treatment of IgG4-related disease: Lessons from 10 consecutive patients. Medicine (Baltimore) 2012; 91(1):57-66. 